\title{
Pandora's War: The Multi-Dimensional Nature of the Yugoslav Conflicts
}

\author{
Slobodan Drakulic
}

This paper is an attempt to define the general nature of armed conflicts in the former Yugoslavia. First, is there a single, and then perhaps polycentric Yugoslav war, or several successive or concurrent wars? Second, is that war, or those wars, civil, international, ethnic, religious, or something else-a combination of two, three, or all four of the above characteristics? Third, why did the war break out? And fourth, who was right and who was wrong in waging it?

The answer to the first question determines the answer to the second one. If there is only one war in the former Yugoslavia, then it should be viewed as a polycentric armed conflict. That premise leads to the conclusion that we are dealing with a Yugoslav civil war fought between several antagonists, and assuming different forms in diverse parts of that multicultural country.

Such interpretation establishes the interconnectedness of the successive armed conflicts in three out of six former Yugoslav republics. It highlights the conflict as war of all against one-predominantly Croat, Muslim and Slovene against the mostly Serb forces. At the same time, it reduces the significance of local, autochthonous factors, picturing them as derivatives of the Yugoslav federal politics. It even maintains an illusion that Yugoslavia may still exist somehow-perhaps as a commonwealth of battlefields.

The Yugoslav republics were distinct and even partially separate ethnic societies and states even before the outbreak of the war. The only exception was Bosnia and Herzegovina, that miniature Yugoslavia which encapsulates the very core of the contradictions that ripped Yugoslavia apart-ethnicity based upon religion that produces

Slobodan Drakulic is a PhD candidate in the Department of Sociology, University of Toronto. an ethnic society governed by an ethnic state guided by the political doctrine of ethnocracy.

At the end of the eighties, Yugoslavia was loose even by the confederal standards, and it entered the nineties as a disorderly society and a disarrayed state. That looseness of Yugoslavia opened sufficient space for autochthonous movements and tendencies to develop in the federal republics, and at once reduced the degree to which anything, including war, could be Yugoslav in nature or in scope.

The series of armed conflicts in the former Yugoslavia could not be defined as a Yugoslav civil war. There simply was not enough Yugoslaviain terms of both state and the peoplefor a Yugoslav civil war. The only Yugoslav state institution left in place was the moribund Yugoslav People's Army, and the only people ready to fight for Yugoslavia were the Serbs of Croatia, Bosnia and Herzegovina, backed by the Serb nationalists of Serbia.

Yugoslav federal army soon was reduced to one of the Serb armies in the former Yugoslavia, composed mostly of the Croatian, and Bosnia-Herzegovinian Serbs (Kruselj, 32). By the Spring of 1992 it was entirely replaced by the local Serb armies, whose political leaderships neither could nor would fight for Yugoslavia. They had to chose between fighting for a Greater Serbia, or for their separate statelettes. They immediately opted for the first goal. Serbian leaders could not dare to accept invitations from their western cousins to annex their lands to Serbia, because of the severe opposition of the mainly Western foreign powers.

The image of Serbs fighting the rest of the former Yugoslavs tends to overshadow the existence of a number of other conflicts that happened within the heterogeneous anti-Serb camp. In one such episode Slovenian troops oc- cupied two small areas of Croatia in 1991, and it took a while before they pulled out (Tudjman, 36). In Bosnia and Herzegovina, a vicious war took place between the Croat and Muslim armed forces in 1993-94. By the time it was stopped by a resolute diplomatic intervention of the belligerents' international patrons, Croat forces were defeated in Central Bosnia, and Muslim forces in the old regional capital of Herzegovina, Mostar, were reduced to an enclave between the Croat forces to the west, and Serb forces in the east. Beneath the dividing lines marked by ethnicity and religion, the Croatian Council of Defense militia (the Bosnian-Herzegovinian Croats' armed force) ambushed and killed members of the Croatian Defense Forces (the party militia of the extreme nationalist Croatian Party of Rights). On the Muslim side, a civil war still goes on between the (Muslim) Army of Bosnia and Herzegovina and the (Muslim) People's Defense Force of the autonomous province of Western Bosnia-led by Fikret Abdic, based in the provincial capital of Kladusa, and the government in Sarajevo accuses the Serbs of backing the West Bosnian Muslim rebels.

Since ethnic lines are not the only lines of division, the number of military formations exceeds the number of major ethnic groups everywhere except in Slovenia, where only two political subjects and two armed forces involved in the war: Slovenian and Yugoslav states and armed forces. In stark contrast to that; there were three major political subjects and about a dozen armed forces involved in the war in Croatia: the Republic of Croatia, Republic of Serb Krajina and Yugoslav Federation, with their assorted armed forces and militias (Gow, 18). The number of major political subjects rose to six in Bosnia and Herzegovina: Republic of Croatia and the Croat Republic of Herceg-Bosna; Republic of

Refuge, Vol. 14, No. 3 (June-July 1994) 
Bosnia and Herzegovina (Izetbegovic) and the autonomous province of Western Bosnia (Abdic); Republic of Srpska (Serb Bosnia and Herzegovina) and the Federal Republic of Yugoslavia (Serbia and Montenegro). The number of armed forces went down, indicating certain stabilization of various state authorities on the ground. Five armed forces confront each other in Bosnia and Herzegovina: two Croat, two Muslim and one Serb. ${ }^{1}$

War in Slovenia is therefore the closest to being a civil war-an ethnic-civil war, the Slovenian war of secession from Yugoslavia. Religious hues were present but not prominent. Slovenia claimed that it was invaded by the Yugoslav People's Army. ${ }^{2}$ The Croatian war is a mixture of the Croatian war of secession from Yugoslavia, and Serb war of secession from Croatia: it thus started as a Yugoslav civil war, but ended as Croatian. As it was fought among ethnic societies governed by ethnic states and inspired by an ideology of ethnocracy, that war took the form of an ethnic war. And as the embattled ethnicities are entwined with religion in those parts (Smith, 27), their war became an ethno-religious war. ${ }^{3}$

War in Bosnia and Herzegovina started as the joint Croat-Muslim war of secession from Yugoslavia, countered by the Serb war of secession from Bosnia and Herzegovina. An additional momentum was the Croat war of secession from Bosnia and Herzegovina-opposed by the Muslim forces. Western Muslim war of secession from Kladusa came as a final stroke on this chaotic martial canvass. Ironically, the almost surrealistic rebellion against the state that is no more, actually provides the only possible dimension of a truly civil war in the whole conflict. Namely, that Mr. Abdic's faction politically disagrees with the pro-Islamic faction of $\mathrm{Mr}$. Izetbegovic, in spite of their common ethnic identity; all other sides in the Yugoslav conflicts politically disagree because of their ethnic differences. ${ }^{4}$

A civil war waged between different ethnic groups in a multi-ethnic so- ciety would end up being an ethnic war. Similarly, every would-be ethnic war fought between opposing ethnicities based on religions would end up being religious war-at least to some degree. ${ }^{5}$ To summarize briefly: first, the armed conflicts in Yugoslavia do not constitute a single Yugoslav civil war; second, those wars are a complex mixture of ethnic, religious, civil, and international armed struggles. Far from being a specie of Clausewitz's kind of war as continuation of politics by other means, they are a series of chaotic martial ruptures-Pandora's wars.

Why did these wars break out? The first and most obvious reason is that the moribund nature of the Yugoslav regime of the time-product of decades of ethnic squabbles and divisions that began in the late sixties. Those ethnic squabbles and divisions in turn promoted internal ethnic homogenization. This process was particularly intensified after the death of the late Yugoslav President Tito, in 1980. By 1990, all ethnic groups were virtually transformed into separate politicalmilitary camps and coalitions of such camps. The level of the political consensus within them was expressed in the series of plebiscites, referenda, elections, and the population census.

Ethnic Serbs of Croatia sought to pre-empt the Croat secession from Yugoslavia with their own separation from Croatia. At their plebiscite in August 1990, the results were as follows: "for autonomy 567,127; against $114 ; 46$ ballots were spoiled" (Bisic, 63). Croatian Serb consensus around the issue of separation from Croatia, if Croatia were to separates from Yugoslavia, was the highest of all ethnic homogenizations at the time.

Slovenian government proclaimed independence from Yugoslavia following a popular plebiscite on the issue, where 86 percent of voters supported the idea of an independent Slovenian state in December of 1990 (Nakarada, 136). By that time, homogenization of the ethnic Slovene public opinion as anti-Serb and anti-Yugoslav had reached the point of no return.
In May of 1991, Croatian government made its final move before the act of secession, calling a referendum. More than 93 percent of all Croatians who cast their ballot, voted for their republic's sovereignty and independence from Yugoslavia (Separovic, 115-17) ${ }^{6}$ Seven percent more than the ethnically far more homogenous Slovenians had cast in December 1990.

On February 29 and March 1, 1992, "some sixty-eight percent of all eligible voters voted in favour of independence," (Fogelquist, 26), at a plebiscite suggested by the European Community and called by the Croat-Muslim coalition's leadership. Most Serbs abstained, obviously. If their numbers were to be subtracted from the total, virtually all adult Croats and Muslims voted for secession. Taken on their own, virtually all Serbs voted against secession.

Finally, on March 1, 1992, "in the referendum in Montenegro, the majority of the people came out for a union of Montenegro and Serbia" (Djuretic, 445). The cycle of ethnic homogenization was thus completed. ${ }^{7}$ As the passions ran high for years before, the assorted Yugoslav political-military camps and coalitions were ready to clash. Pandora's box was brimming with wars.

At that point in time, there was no major ethnic group left in Yugoslavia which was not politically homogenized around an ideological political consensus already established by the ethno-nationalist Communists, and hardened by the new political elites that conquered the state power in $1990 .^{8}$ All those elites were leaning towards pronounced ethno-nationalist stands that were about to throw the country into war.

All that was needed by the beginning of the nineties, was someone to merely touch upon someone else's sore psychohistoric spot, and things would take the course towards confrontation. No such thing happened in Yugoslavia. Nobody touched anybody's sore spot: they trampled upon them whenever and wherever they could, with both feet stuck into military boots. 
Take for example the phonogram of a secret meeting held on July 23, 1990, of the President of Croatia, Franjo Tudjman and his advisor, Slaven Letica, with the leader of Croatian Serbs of the time, Jovan Raskovic. At one point, Raskovic says: "I have also pleaded to you to mention the sovereignty of the Serb national being. That is not a state sovereignty of any kind, when you say that sovereignty of the Serb national being is being recognized ...." President Tudjman responded: "Those are legal formulations." His advisor Letica added: "That cannot be improvised. Croatia is the national state of the Croats" (Letica, 154), (Raskovic, 312).
Gypsies and Jews (mostly), and Serbs. This was one of the particularly sore spots of both Serbs and Croats, repeatedly entered by Mr. Tudjman in his capacity of a revisionist historian of the World War II horrors (Babic, 79). 9 Croat propagandists retorted by means of books like the one edited by Boze Covic and titled The Origins of the Great-Serbian Aggression, proving that Serb intellectuals and politicians had aimed to attack Croatia ever since 1844 (Covic, Izvori)..$^{10}$

In Bosnia and Herzegovina, Alija Iztbegovic's Islamic Declaration was published in 1990 (two odd decades after having been written), subtitled "A Programme for the Islamization of

\section{Why did these wars break out? The first and most obvious reason is that the moribund nature of the Yugoslav regime of the time- product of decades of ethnic squabbles and divisions that began in the late sixties.}

The issue at stake was definition of the state of Croatia in the new Constitution that was then being prepared. Croat ruling party wanted to define it in Letica's terms. Most Croatian Serbs insisted that they should be mentioned as a co-sovereign people of Croatia.

Letica's blunt definition of Croatia did not enter the Constitution (Constitution, 31), but it entered the corpus of the casus belli. About a month earlier, Serbian leader Slobodan Milosevic offered his contribution to the brewing war: "Serbia should let it be clearly known that it takes its present administrative borders only in connection with a federally constituted Yugoslavia," and "in case that such a Yugoslavia is not wanted, the issue of Serbia's borders is an open question" (Cavoski, 136-37). What was not accomplished by the politicians had been achieved by the propagandist intellectuals. In the first half of 1991, before the Slovenian and Croatian declarations of independence, Petar Dzadzic published the third expanded edition of his book The New Ustasha State?, relating Franjo Tudjman to the Nazi Croat Führer in 1941-45, Ante Pavelic, responsible for the deaths of hundreds of thousands of
Muslims and the Muslim Peoples" (Izetbegovic, 3). I am not sure that Mr. Izetbegovic's political theology could have impressed very many largely religiously indifferent Bosnian Muslims. I do know that its publishing was successfully used for the Serb ethnic mobilization against the Islamic fundamentalist revival of Alija Izetbegovic, promoted by the Serbian media.

Slovenian media churned their own "flowers of political and intellectual evil," like everybody else. One of the protagonists of the Slovene new social movements, Tomaz Mastnak, announced:" I see no solution and have ceased looking for one," (Mastnak, 48) in a situation where Yugoslavia was split into "two opposing models of social and political development ... one Slovenian and the other Serbian" (Mastnak, 46). The period of 1989-91 could be defined as one protracted psychosocial preparation for war-on all sides without exceptions.

The remaining question is the one of right and wrong involved in these wars. By late June 1991, when war erupted in Slovenia, a low-level warfare was already going on in Croatia since August of 1990. According to the local ethnic Serb sources, it all started on "August 17, 1990 lat the Northern Dalmatian municipality of] Benkovac," after the "Ministry of Internal Affairs of Croatia sentits special troops to prevent the plebiscite," due to be held within two days. "Serbs responded by erecting barricades," and the "war for Krajina started" (Bisic, 63). ${ }^{11}$ Another Serb source from Belgrade states that "the'Serb uprising' in the Knin Krajina ${ }^{12}$ practically started," as a "response to a night attack of the 'specials' ${ }^{13}$ against the militia ${ }^{14}$ station in Benkovac" (Nakarada, 135).

The ethnic Croat sources reported the same event very differently. Well known Croat writer Dubravko Jelcic wrote in his diary that "military planes intercepted the official helicopters of the Ministry of Interior of Croatia, forcing them to return to their base," which is how "an open attack on Croatia started." (Jelcic, 254-55). Another Croat writer maintained that the Serbo-Croat standoff in the area of Knin was " planned in the Serbian ideological centres;" local Serbs, "encouraged by two MIGs in the sky and meetings of support in Serbia, actually declared war on Croatia" (Cuic, 9).

That was a fact confirmed by the other side in the conflict as well. On August 17, 1990, the President of Knin municipality, Milan Babic, proclaimed the state of war on the local radio. The last President of Yugoslavia and Croatian separatist Stipe Mesic cracked a joke about this incident, saying that "Mr. Babic must be a big joker when he thinks that President of a municipality can proclaim the state of war." Dubravko Jelcic who preserved Mr. Mesic's pun for posterity, commented about his own reaction to the joke: "I laughed from my heart and immediately felt the power of humour: what has once been ridiculed, cannot be serious, let alone lofty, any more" (Jelcic, 255).

On the contrary, something can be deadly serious, regardless of how much it may have been ridiculed by its opponents. Mr. Babic's declaration of war may have been pathetic, but the

Refuge, Vol. 14, No. 3 (June-July 1994) 
fact remains that the President of the thinly inhabited badlands which is the municipality of Knin, was right: the war in former Yugoslavia started on August 17, 1990 in Benkovac, Croatia; if one prefers to talk about more than one war, than this was the first in the series, and it started with Mr. Babic's proclamation of the state of war in Knin.

That initial stage of the armed conflict is marked by the Croatian secession from Yugoslavia, and Serbian resistance to it, which manifested itself as the local Serb secession from Croatia. As two sides in this conflict were indigenous to Croatia, theirs was a civil war. Furthermore, as Croatia and all participants in the Croatian conflict at least formally belonged to Yugoslavia, that war was not ethnic, but civil as well. After the international recognition of Croatia as an independent state, that war became international and remained such until the Yugoslav Army's pull-out from its territory.

The Slovene state leadership hence faced a situation where an armed conflict was already in full motion in Croatia, involving ethnic Croat-led and dominated forces on one side, and equally ethnic Serb forces on the other. Slovenian leaders watched the federal army as it vacillated between an untenable neutrality and growing sympathies with the Croatian Serbs by most of its mostly Serb and Montenegrin, as well as mostly pro-Yugoslav federalist Communist professional military officers. They should have had no illusions about the side that those same officers would chose in an armed conflict in Slovenia.

One should bear in mind that Slovenia was the primary battleground between the increasingly ethno-nationalist and separatist Slovenian new social movements, and the steadfastly federalist Yugoslav People Army's officer corps. Slovenia's Minister of Defence since 1990, Janez Jansa, was one of the four people put on tried for treason in 1988 , by a military tribunal, after rendering public some military documents of highly disputable impor- tance, to say the least, that were stamped as "strictly confidential" by some anonymous and probably unconcerned military bureaucrat.

That trial seems to have been the breaking point in the relationship between the mainstream ethnic Slovene population and the Yugoslav regime, and particularly its military authorities. This is was indicated at the time by the Slovene political analyst Darko Strajn, who asked whether any change at all could be affected within the existent framework (Grakalic, 146-48). The implication is obvious: if no reform was possible, the Slovene new social movements would have to give up their aspirations, or make a dash for the political revolution. They opted for the latter, backed by their state and party apparatus during the Communist regime. Their struggle was continued by the new separatist regime that bore even some clericalist-nationalist hues.

With such sharply antagonistic forces dominating their respective areas of the political spectrum of the former Yugoslavia, war became increasingly unavoidable. The spark was purposely provided by the Slovenian government, and set to the Yugoslav tinderbox by its Ministry of Defense (Jansa, 155). ${ }^{15} \mathrm{Mr}$. Jansa's passionate struggle to start a war in Slovenia met an equally zealous response from his government's opponents in Belgrade.

Consequently, when the Slovenian Territorial Defence units took Yugoslav border crossings to Italy, Austria and Hungary by force, federal Prime Minister Ante Markovic responded by ordering the federal army to retake them by force. The army rolled out in its armour-but with a vastly insufficient infantry of less than two thousand soldiers-and swept the lightly armed Slovene militias aside. Most border crossings were back under the federal government's control within days. In the meantime, nine Slovenian militiamen were killed in the clashes (Jansa, 5); some scores of federal troops died on the other side (Bandi, 202); some foreigners were drawn into the maelstrom by the Slovenian troops- used as a human shield of a kind-and were killed by the federal forces (Molinari, 50), their number of ten being only somewhat lower than that of the ethnic Slovenes (Bandi, 202).

Within days, foreign powers intervened, offering mediation and asking for the cessation of hostilities. A standoff followed, with Slovenian independence being suspended no more than the federal control over Slovenia evaporated into thin air. On July 1 1991, the Serbian side was pressured by international factors to accept an ethnic Croat secessionist, Mr. Stipe Mesic, as the President of the Yugoslav federal Presidency. He thus became the head of the highest instance of state power in the country-formally a head of the collective supreme commander of the Yugoslav People's Army.

Several days later, an accord between the belligerents was signed at the late President Tito's resort at the Islands of Brioni (later on renamed by the Croatian state into Brijuni). The war in Slovenia was over-if it ever happened. What did happen, however, was a series of low-scale clashes of no tactical significance, not to mention any strategic importance.

An intensive propaganda war happened instead, with Croatia and Slovenia on one side, and the federal government, Montenegro and Serbia on the other. Croatian and Slovenian propagandists claimed that their countries had suffered an aggression of the Yugoslav federal army, while the same army accused their Slovene antagonists of high treason. ${ }^{19}$ Both arguments were vacuous from the other's point of view, and, needless to say, both protagonists practised an autistic form of political behaviour, utterly oblivious to anything beyond their obsessive goals.

The fundamentally identical political process that led to the war in Croatia, was repeated in Bosnia and Herzegovina. First Serbo-Muslim clashes occurred in the town of Foca, on September 11, 1990, less than a month after the first armed standoff in Croatia. For as long as the ethnically tripartite Presidency, Parliament and 
government of the republic were in place, the balance of power kept the situation from a precipitous deterioration. Gradual worsening of ethnic relations continued nonetheless.

The first free elections held in November of 1990 , confirmed the process of ethno-political homogenization. Electoral results actually looked like an ethnic census data: Muslim Party of Democratic Action won 86 seats in the new Parliament; Serb Democratic Party 72; Croat Democratic Community 44 (Nakarada, 136).

By April of 1991, predominantly ethnic Serb region of Bosnian Krajina ${ }^{17}$ founded its own Assembly (Parliament (Nakarada, 139). In late October of 1991, an Assembly (Parliament) of the Serb people of Bosnia and Herzegovina was founded (Bisic, 66), in response to the mid-October Memorandum on the Sovereign Bosnia and Herzegovina, adopted by the CroatMuslim majority in the Parliament (Bisic, 65). In November, Serb people of Bosnia and Herzegovina held a plebiscite, expressing their intention to remain in Yugoslavia (Nakarada, 146). A month later, Government and Presidency of Bosnia and Herzegovina decided to seek recognition from the European Community as an independent state. Serb representatives were outvoted again, by the CroatMuslim coalition (Bisic, 66).

Then came the Croat-Muslim backed declaration of independence, wide international recognition, and breakup of Bosnia and Herzegovina, all in the Spring of 1992. What followed was a maelstrom of war, where yesterday's allies cut each others' civilians' throats or burned them alive in their homes.

The lust of war was on the loose as villainy marched under the ethnic flags, torturing, slaughtering, raping, plundering, wrecking, even heädhunting. ${ }^{18}$ All in the name of the people, nation, gods, history, freedom-one vast collective endeavour inspired by ethnic hatred, and dedicated to the joy of wanton destruction. In a way, this Pandora's War is indeed beyond good and evil. It is insane.

\section{Notes}

1. If we discount the Croatian Defence Forces, which may have no future, especially having in view that several political and military leaders were already killed by other Croat forces under questionable circumstances.

2. Such claims were made by all sides, including the Serbs. For the Slovene story see Jansa; Croatian story can be found in Covic; Muslim story is told by Fogelquist; Serb story is in Djuretic; for Yugoslav federal story see Kadijevic. These are just examples, of course.

3. I will leave alone the international dimensions of the Balkan conflicts, because such an attempt would require a comparative assessment of not only Yugoslav (Serbian and Montenegrin) role in them, but also the arming of Croatia and Slovenia by Germany, Austria and Hungary in $1990 / 91$, or the recent American and British involvement in the Balkan conflicts on the Muslim side, which is far too complex an issue for the scope of this paper.

4. I am taking ethnic difference in the sense of subjective self-understanding, although I am fully aware of their concrete material and historical vacuousness.

5. The issue of faith and religious sincerity is another matter which I cannot pursue in this paper.

6. Let me note that the voting slip for sovereignty and independence was blue, and represented as a Croatian-Slovenian position; the other voting slip was red, it asked the voter to be for a "single federal country of Yugoslavia" - suggesting union instead of federation-and it was represented as a Serbian-Montenegrin proposal.

7. Here we encounter the much disputed issue of ethnicity of the Montenegrins. It,seems to me that most of them were leaning towards closer ties with Serbia, ever since the mass uprising against the local Titoist epigones in 1988-89 (Strugar, 41). To counterbalance Strugar's Serb nationalist views, one can consult a Montenegrin independentist like Brkovic, for example.

8. Montenegro and Serbia went through a different process, wherein former Communists quite swiftly converted to Serb nationalism in 1987-89. Slobodan Milosevic is certainly the most famous example. Expounding anti-nationalist political viewpoint as late as December 1986 (Milosevic, 126-28), he was a national-communist leader of Serbia by the Spring of 1987 (Milosevic, 147-48, for example). His Montenegrin counterpart is Momir Bulatovic, who was pro-Yugoslav in 1989 (Bulatovic, 37), but ended up clashing with Slovene leadership in 1991, as we can see from his letter to the Slovenian President Milan Kucan (Bulatovic, 214-15).

9. It was his historical revisionism and nationalism that turned Tudjman into a dissident, not his rather nebulous democratic orientation (Babic, 83).
10. Although terribly slanted, this is a valuable sourcebook of Serbo-Croat ethnic relations, nonetheless.

11. Militärgrenz, Vojna Krajina, Military Frontier against the Ottoman Empire, demilitarized in 1881 and annexed to Croatia and Slovenia. Namely, Croatia was a "triune" kingdom at that time, composed of Croatia (North-West), Slovenia (North-East), and Dalmatia (coastal regions). Dalmatia went from being a Venetian possession for centuries, through a short French rule during Napoleon I, to being an Austrian territory until 1918, when it entered the Kingdom of the Serbs, Croats, and Slovenes, which in turn became Yugoslavia in 1929. A good and fair short history of the Military Frontier can be found in Roksandic.

12. A medieval toponym referring to the area around the municipality of Knin, in Northern Dalmatia, presently capital of the selfproclaimed Republic of Serb Krajina.

13. Commando units of the Ministry of Interior of Croatia.

14. Militia in this instance means the police.

15. That "highest state secret" was "known by only a few people (expanded Presidency [of Slovenia], some members of the government, and the key operative personnel" (Jansa, 155).

16. As both ministers of defense-Slovenian and Yugoslavian-have published their memoirs, one may find it useful to compare their accounts of the events. See Jansa and Kadijevic in references.

17. Western Bosnia, with the regional capital of Banja Luka.

18. See Amnesty International and Helsinki Watch reports on the war crimes in Croatia and Bosnia-Herzegovina. About headchopping, see Soldo.

\section{References}

Amnesty International. 1992. Bosnia-Herzegovina-Grossabuses of basichuman rights. London: Amnesty International, October.

Amnesty International. 1993. Bosnia-Herzegovina-Rana u dusi-A wound to the soul. London: Amnesty International, January.

Amnesty International: 1993. Bosnia-Herzegovina-Rape and sexual abuse by armed forces. London: Amnesty International, January.

Babic, Goran. 1992. Bespuca Franje Tudjmana. Zemun: Grafopublik.

Bandi Federica, Marcello Barzelogna, Franco Casseler, Alessandro Ciocchi, Piero Del Giudice, eds. 1991. I giomi della Slovenia-25 giugno/10 luglio. Trieste: Edizioni e.

Bisic, M. 1992. "Hronologija vaznijih dogadjaja 1987-1992," Pogledi, May 8, pp. 63-66.

Brkovic, Jevrem. 1990. Lideri, udbasi, generali. Zagreb: Centar za informacije i publicitet.

Bulatovic, Momir. 1991. Manje od igre-vise od zivota. Novi Sad: Buducnost.

Cavoski, Kosta. 1991. Slobodan protiv slobode. Beograd: Dosije.

1991. The Constitution of the Republic of Croatia. Zagreb: Sabor Republike Hrvatske. 